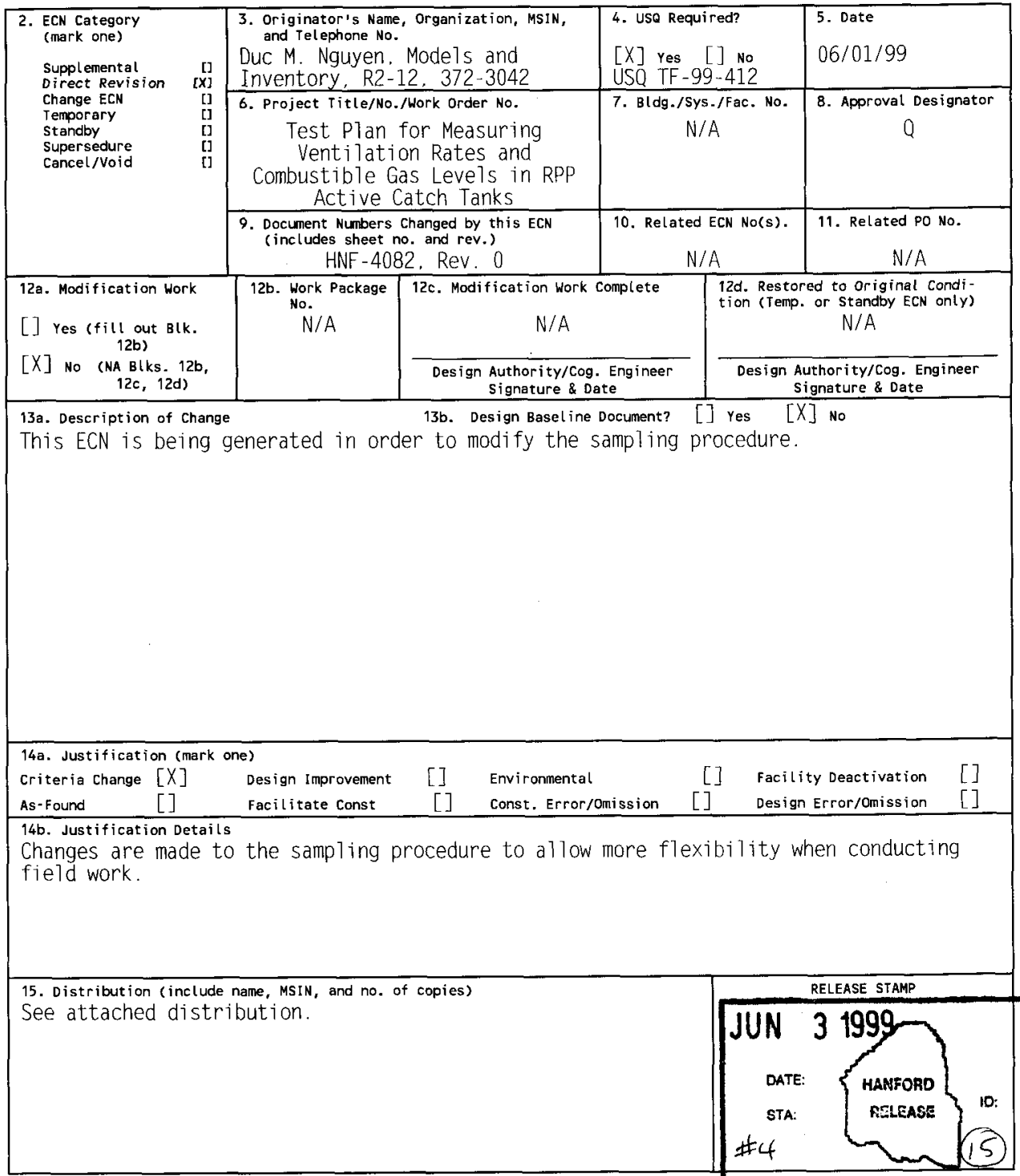




\begin{tabular}{|c|c|c|c|c|c|}
\hline $\begin{array}{l}\text { 16. Design } \\
\text { Verification } \\
\text { Required }\end{array}$ & 17. Cost $1 \mathrm{~m}$ & & & & 18. Schedule \\
\hline [] Yes & Additional & $\$$ & Additional & $\$$ & Improvement \\
\hline$[X]$ No & Savings & $\$$ & Savings & $\$$ & Delay \\
\hline
\end{tabular}

19. Change Impact Review: Indicate the related documents (other than the engineering documents ident ified on Side 1) that will be affected by the change described in Block 13 . Enter the affected document number in Block 20.

$\begin{array}{ll}\text { SDDiDD } & {[]} \\ \text { Functional Design Criteria } & {[]} \\ \text { Operating Specification } & {[]} \\ \text { Criticality Specification } & {[]} \\ \text { Conceptual Design Report } & {[]} \\ \text { Equipment Spec. } & {[]} \\ \text { Const. Spec. } & {[]} \\ \text { Procurement Spec. } & {[} \\ \text { Vendor Information } & {[]} \\ \text { OM Manual } & {[]} \\ \text { FSAR/SAR } & {[]} \\ \text { Safety Equipment List } & {[]} \\ \text { Radiation Work Permit } & {[]} \\ \text { Environmental Impact Statement } & {[]} \\ \text { Environmental Report } & {[]} \\ \text { Environmental Permit } & {[]}\end{array}$

[] Seismic/Stress Analysis

[] Stress/Design Report

[] Interface Control Drawing

[] Calibration Procedure

[]

[]

[]
[]

[]

Installation Procedure

Maintenance Procedure

Engineering Procedure

Operating Instruction

Operating Procedure

Operational Safety Requirement

IEFD Drawing

Cell Arrangement Drawing

Esseritial Material Specification

Fac. Proc. Samp. Schedule

Inspection Plan

Inventory Adjustment Request
Tank Calibration Manual

Health Physics Procedure

Spares Multiple Unit Listing

Test Procedures/Specification

Component Index

ASME Coded item

Human Factor Consideration

Computer Software

Electric Circuit Schedula

ICAS Procedure

Process Control Manual/Plan

Process Flow Chart

Purchase Requisition

Tickler File

[] Tickler File

20. Other Affected Documents: (NOTE: Documents listed below will not be revised by this ECN.) Signatures below indicate that the signing organization has been notified of other affected documents listed below. Document Number/Revision Document Number/Revision Document Number Revision $N / A$

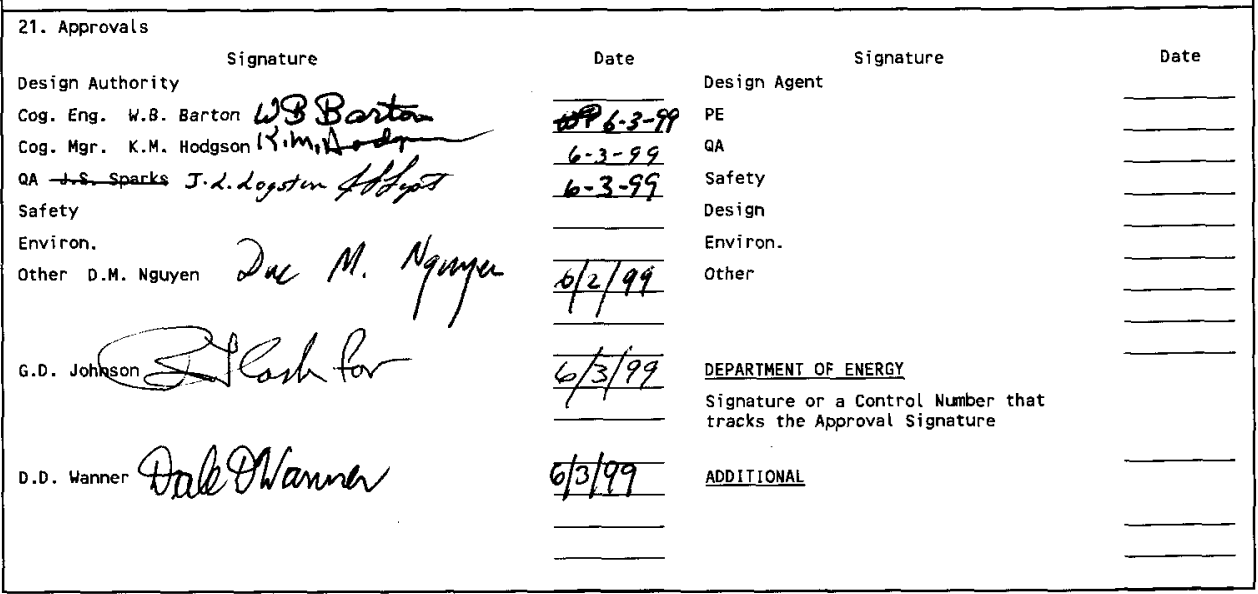


$S$

HNF - 4082, Rev. 1

\title{
Test Plan for Measuring Ventilation Rates and Combustible Gas Levels in RPP Active Catch Tanks
}

\author{
D. M. Nguyen
}

Lockheed Martin Hanford, Corp. , Richland. WA 99352

U.S. Department of Energy Contract DE-AC06-96RL13200

$\begin{array}{lll}\text { EDT/ECN: } & \text { ECN }-653821 & \text { UC: } 2070 \\ \text { Org Code: } & 74 B 40 & \text { CACN/COA: 101921/CB80 } \\ \text { B\&R Code: } & \text { EW 3120074 } & \text { Total Pages: 31(JKB 6/3/99) }\end{array}$

Key Words: Test Plan. Measuring, Ventilation Rates, Ventilation, Combustible Gas Levels, Gas. TWRS, Active Catch Tanks. Active, Catch Tanks

Abstract: $\quad N / A$

TRADEMARK DISCLAIMER. Reference herein to any specific commercial product, process, or service by trade name, trademark, manufacturer, or otherwise, does not necessarily constitute or imply its endorsement, recommendation, or favoring by the United states Government or any agency thereof or its contractors or subcontractors.

Printed in the United States of America. To obtain copies of this document, contact: Document Control Services, P.0. Box 950, Mailstop H6-08, Richland WA 99352, Phone (509) 372-2420; Fax (509) 376-4989.
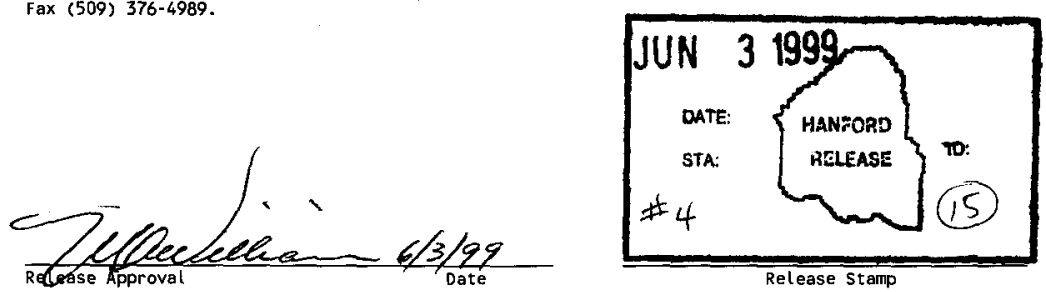

\section{Approved for Public Release}




\section{RECORD OF REVISION}

(1) Document Number

HNF - 4081

(2) Title

Test Plan for Measuring Ventilation Rates and Combustible Gas Levels in RPP Active Catch Tanks

\begin{tabular}{|c|c|c|c|c|c|}
\hline & \multirow{2}{*}{ Revision } & \multirow{2}{*}{\multicolumn{2}{|c|}{ (4) Description of Change - Replace, Add, and Delete Pages }} & \multicolumn{2}{|c|}{ Authorized for Release } \\
\hline & & & & (5) Cog. Engr. & (6) Cog. Мgr. Date \\
\hline & 0 & & $\begin{array}{l}\text { Initially released } 03 / 15 / 99 \text { on EDT- } \\
611453 \text {. }\end{array}$ & W.B. Barton & K.M. Hodgson \\
\hline & ${ }^{1} \mathrm{RS}$ & & Incorporate per ECN-653821. & W.B.Barton & K.M.M.Hodgson \\
\hline & & & & & \\
\hline & & & & & 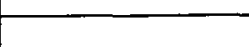 \\
\hline & & & & & \\
\hline & & & & & \\
\hline & & & & & \\
\hline & & & & & \\
\hline & & & & & \\
\hline & & & & & \\
\hline & & & & & \\
\hline & & & & & \\
\hline & & & & & \\
\hline & & & & & \\
\hline & & & & & \\
\hline & & & & & \\
\hline & & & & & \\
\hline & & & & & \\
\hline & & & & & \\
\hline & & & . & & \\
\hline & & & & & \\
\hline & & & & & \\
\hline & & & & & \\
\hline & & & & & \\
\hline & & & & & \\
\hline & & & & & \\
\hline & & & & & \\
\hline & & & & & \\
\hline & & & & & \\
\hline & & & & & \\
\hline & & & & & \\
\hline
\end{tabular}




\title{
TEST PLAN FOR MEASURING VENTILATION RATES AND COMBUSTIBLE GAS LEVELS IN RPP ACTIVE CATCH TANKS
}

\author{
D. M. Nguyen \\ Lockheed Martin Hanford Corporation
}

Date Published

June 1999

Prepared for the U. S. Department of Energy

Assistant Secretary for Environmental Management

Project Hanford Management Contractor for the

U.S. Department of Energy under Contract DE-AC06-96RL13200

Approved for public release; distribution is unlimited 
TABLE OF CONTENTS

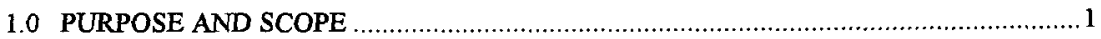

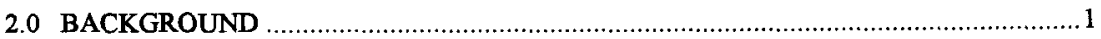

3.0 OVERALL DESCRIPTION OF TEST

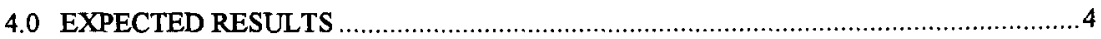

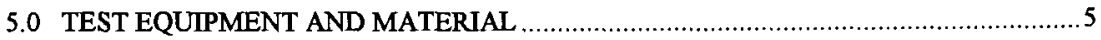

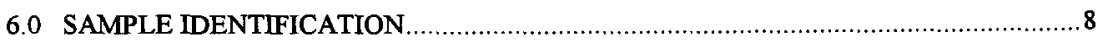

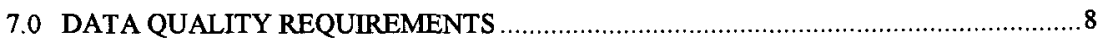

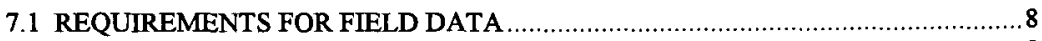

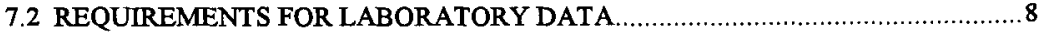

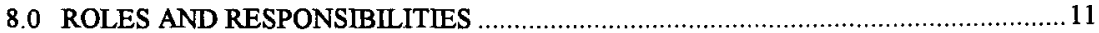

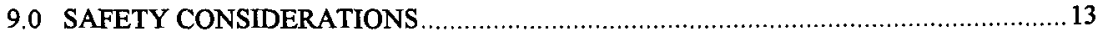

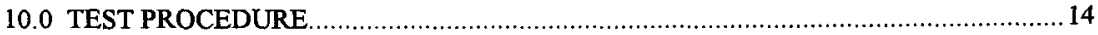

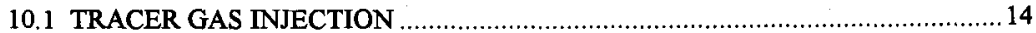

10.2 FIELD COMBUSTIBLE GAS LEVEL MEASUREMENTS ...............................16

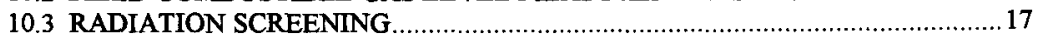

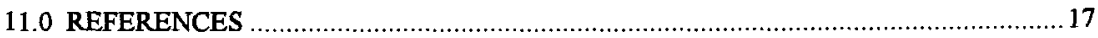

\section{APPENDICES}

A. 0 METHOD FOR CALCULATING VENTILATION RATE IN A CATCH TANK ….....A-1

B.0 DATA SHEET FOR USE WITH TRACER GAS INJECTION …….......................... B-1 


\section{LIST OF FIGURES}

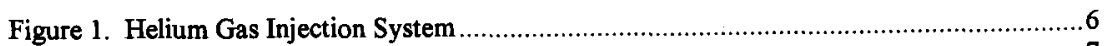

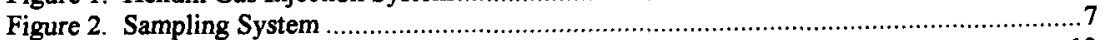

Figure 3. Lead Roles for the Sampling Activity ...................................................... 12

\section{LIST OF TABLES}

Table 2-1. RPP Catch Tanks .............................................................................. 1

Table 3-1. Data Needs and Associated Measurement Methods ......................................... 3

Table 3-2. Analytes of Interest if Combustible Gas Level Exceeds $25 \%$ of the Lower Flammability Limit ......................................................................... 3

Table 7-1. Suggested Analytical Methods and Laboratory Quality Control Requirements .........9

\section{LIST OF TERMS}

CGM combustible gas monitor

CPO Characterization Project Operations

DB diversion box

gal gallon

LFL lower flammability limit

OVM organic vapor monitor

ppm parts per million

$\%$ percent

psig pounds per square inch gauge

RQL required quantitation limits

SAS Special Analytical Support

SOP standard operating procedure

RPP River Protection Project

USQ unreviewed safety question

WSCF Waste Sampling and Characterization Facility 


\section{TEST PLAN FOR MEASURING VENTILATION RATES AND COMBUSTIBLE GAS LEVELS IN RPP ACTIVE CATCH TANKS}

\subsection{PURPOSE AND SCOPE}

The purpose of this test is to provide an initial screening of combustible gas concentrations in catch tanks that currently are operated by River Protection Project (RPP). The data will be used to determine whether or not additional data will be needed for closure of the flammable gas unreviewed safety question for these facilities.

This test will involve field measurements of ammonia, organic vapor, and total combustible gas levels in the headspace of the catch tanks. If combustible gas level in a tank exceeds an established threshold, gas samples will be collected in SUMMA ${ }^{1}$ canisters for more extensive laboratory analysis. In addition, ventilation rates of some catch tanks will be measured to evaluate removal of flammable gas by air flow through the tanks.

\subsection{BACKGROUND}

In general, RPP catch tanks were designed to collect leaks, spills, condensation, and drainage that might occur during operation of tank farm diversion boxes (DBs), valve pits, and pipeline encasement. Volume and constituents of the material in these tanks vary depending on the operations of the Tank Farm facilities. Most of these tanks are expected to contain small amounts of organic chemicals and low levels of radioactivity. Thus, flammable gases could be generated and accumulated in these tanks; however, the levels are expected to be very low. A list of the RPP active catch tanks is shown in Table 2-1. Tank capacity, material of construction, and ventilation type (active or passive) are also provided.

Table 2-1. RPP Catch Tanks (2 Sheets)

\begin{tabular}{|c|c|c|c|c|c|}
\hline 1tentin. & Hank mo vo & Intorral Mugac & Moninar & Gonstiviction & Woriting \\
\hline 1 & 241-A-302A & $\begin{array}{l}\text { Drainage from } D B \\
241-A-151\end{array}$ & $8,400 \mathrm{gal}$ & Carbon steel & No \\
\hline 2 & 241-A-350 & $\begin{array}{l}\text { Drainage from A } \\
\text { Farm }\end{array}$ & $800 \mathrm{gal}$ & Stainless steel & No \\
\hline 3 & 241-A-417 & $\begin{array}{l}\text { Drainage from } 241 \text { - } \\
\text { AY/AZ vent }\end{array}$ & $44,000 \mathrm{gal}$ & $\begin{array}{c}\text { Concrete } \\
\text { vault with } \\
\text { carbon steel } \\
\text { liner }\end{array}$ & No \\
\hline
\end{tabular}

\footnotetext{
${ }^{1}$ SUMMA is a trademark of Moletrics, Inc., Cleveland, Ohio.
} 
Table 2-1. RPP Catch Tanks (2 Sheets)

\begin{tabular}{|c|c|c|c|c|c|}
\hline 1ren. & 6ring & 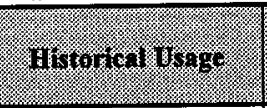 & 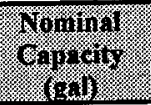 & 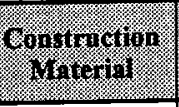 & 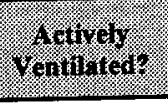 \\
\hline 4 & $241-A X-152$ & $\begin{array}{l}\text { Drainage from AX- } \\
152 \text { diversion station, } \\
\text { DB } 241-\mathrm{AX}-155 \text {, } \\
\text { AY-501, and } 702-\mathrm{A} \\
\text { seal pot }\end{array}$ & $11,000 \mathrm{gal}$ & $\begin{array}{l}\text { Concrete } \\
\text { vault with } \\
\text { steel liner }\end{array}$ & $\begin{array}{c}\text { Yes } \\
\text { (indirectly } \\
\text { from 702-AZ } \\
\text { system) }\end{array}$ \\
\hline 5 & 241-AZ-151 & $\begin{array}{l}\text { Drainage from DB } \\
\text { 241-AZ-152, AZ } \\
\text { vent. Loop seals, leak } \\
\text { detection pits, 801- } \\
\text { AZ Instrumentation } \\
\text { Building and } \\
\text { precipitation/runoff }\end{array}$ & $12,000 \mathrm{gal}$ & $\begin{array}{l}\text { Concrete } \\
\text { vault with } \\
\text { carbon steel } \\
\text { liner }\end{array}$ & $\begin{array}{c}\text { Yes } \\
\text { (indirectly } \\
\text { from 702-AZ } \\
\text { system) }\end{array}$ \\
\hline 6 & 241-AZ-154 & $\begin{array}{l}\text { Drainage from AZ- } \\
101 \text { and } A Z-102 \\
\text { steam coils and } \\
\text { precipitation/runoff }\end{array}$ & $900 \mathrm{gal}$ & $\begin{array}{c}\text { Concrete } \\
\text { vault with } \\
\text { carbon steel } \\
\text { liner } \\
\end{array}$ & $\begin{array}{c}\text { Yes } \\
\text { (indirectly } \\
\text { from } 702-\mathrm{AZ} \\
\text { system) } \\
\end{array}$ \\
\hline 7 & 241-ER-311 & $\begin{array}{l}\text { Drainage from DBs } \\
151-E R \text { and } 152-E R\end{array}$ & $18,000 \mathrm{gal}$ & Carbon steel & No \\
\hline 8 & 204-AR-TK-1 & $\begin{array}{l}\text { Drainage from the } \\
\text { 204-AR Waste } \\
\text { Unloading Facility } \\
\text { unloading canyon. }\end{array}$ & $1,500 \mathrm{gal}$ & Stainless steel & Yes \\
\hline 9 & 241-S-304 & $\begin{array}{l}\text { Drainage from DB } \\
241-\mathrm{S}-151 \text { and } \\
\text { precipitation/runoff }\end{array}$ & $6,000 \mathrm{gal}$ & Carbon steel & No \\
\hline 10 & 241-TX-302C & $\begin{array}{l}\text { Drainage from DB } \\
241-\mathrm{TX}-154 \text { and } \\
\text { precipitation/runoff }\end{array}$ & $18,000 \mathrm{gal}$ & Carbon steel & No \\
\hline 11 & 241-U-301B & $\begin{array}{l}\text { Drainage from DBs } \\
241-\mathrm{U}-151,241-\mathrm{U}- \\
152,241-\mathrm{U}-153,241- \\
\mathrm{U}-252\end{array}$ & $36,000 \mathrm{gal}$ & $\begin{array}{l}\text { Concrete } \\
\text { (unlined) }\end{array}$ & No \\
\hline 12 & 241-UX-302A & $\begin{array}{l}\text { Drainage from DB } \\
241-\mathrm{UX}-154,291-\mathrm{U} \\
\text { stack, and } \\
\text { precipitation/runoff }\end{array}$ & $18,000 \mathrm{gal}$ & Carbon steel & No \\
\hline 13 & 241-EW-151 & $\begin{array}{l}\text { Drainage from the } \\
\text { former cross-site } \\
\text { transfer vent station }\end{array}$ & $800 \mathrm{gal}$ & Carbon steel & No \\
\hline
\end{tabular}




\subsection{OVERALL DESCRIPTTON OF TEST}

The baseline flammable gas content of each catch tank and the ventilation rates in two of the tanks will be measured. Gas levels will be measured in the field using portable or hand-held gas meters. Ventilation rates will be determined using the tracer gas injection method. These methods have been used successfully for waste tanks and double-container receiver tanks (Bauer 1998 and Bauer and Hedengren 1999). The gas level and ventilation rate measurement methods are specified in Table 3-1.

Table 3-1. Data Needs and Associated Measurement Methods

\begin{tabular}{|c|c|}
\hline Bat & 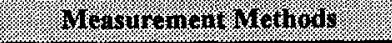 \\
\hline Combustible gas level & Combustible Gas Monitor (CGM) \\
\hline Ammonia & Calorimetric (Draeger) Tubes \\
\hline Organic vapor & Organic Vapor Monitor \\
\hline Ventilation Rate & Tracer gas (Helium) injection \\
\hline
\end{tabular}

Flammable gas levels in the headspace of each catch tank will be measured. Prior to taking the measurements, the sampling system will be purged to assure that the sample system tubing is filled only with headspace gas. If the combustible gas level in a tank as measured by the CGM exceeds $25 \%$ of the lower flammability limit (LFL), three SUMMA ${ }^{\text {TM }}$ canister samples will be collected for vapor gas characterization. These SUMMA ${ }^{\text {TM }}$ samples would be analyzed for parameters listed in Table 3-2.

Table 3-2. Analytes of Interest if Combustible Gas Level Exceeds $25 \%$ of the Lower Flammability Limit

\begin{tabular}{|l|l|}
\hline Carbon Monoxide & Oxygen \\
Carbon Dioxide & Nitrous Oxide \\
Hydrogen & Ammonia \\
& Organic Compounds (See Table 6.1) \\
\hline
\end{tabular}

The ventilation rates in the RPP active catch tanks are not known and are expected to vary. Some tanks are passively ventilated; others are connected to an active ventilation system (702-AZ). The passively ventilated tanks either have breather filters or are connected to other systems that have air filters. Two tanks, 241-AX-152 and 241-A-417 (representing actively and 
passively ventilated tanks, respectively), have been selected for measurement to provide a preliminary indication of flammable gas removal rate due to air flow through the tanks.

Helium will be injected into the headspace of a designated tank through an assigned injection point as specified by the sampling cognizant engineer. The sampling cognizant engineer will specify the required volume of helium based on measured decrease in pressure of the gas supply. Two SUMMA ${ }^{\mathrm{TM}}$ samples will be collected after allowing the helium to disperse evenly throughout the tank headspace. One additional set of two SUMMA ${ }^{\text {TM }}$ samples (and an optional third set of samples) will be collected at a time interval to be specified by the sampling cognizant engineer. These SUMMA ${ }^{\mathrm{TM}}$ samples will be analyzed for helium concentration only. Ventilation rate in the tank will be calculated based on the measured decay in helium concentration between these points in time. The calculation method is derived and described in Appendix A.

Note that the tests described in this plan will provide screening data only. A comprehensive evaluation of potential variables (i.e., factors that could affect combustible gas generation or retention in a catch tank), such as volume, composition, and temperature of the waste and atmospheric conditions, etc., are outside the scope of this effort. However, these data will be recorded if available.

\subsection{EXPECTED RESULTS}

For each catch tank, combustible gas level (in \%LFL), ammonia concentration (in parts per million [ppm]), and organic vapor level (in ppm) will be measured and reported. The levels of these gases and vapors in the catch tanks are expected to be very low.

Tank 241-AX-152 headspace is indirectly connected to the 702-AZ ventilation system and, thus, is considered an actively ventilated tank. This tank is expected to have a much higher ventilation rate than that of the passively ventilated tank 241-A-417. 


\subsection{TEST EQUIPMENT AND MATERIAL}

Test equipment needed for each catch tank include:

- Combustible Gas Meter (CGM) for measuring combustible gas level,

- Organic Vapor Monitor (OVM) for measuring organic vapor concentration,

- Calorimetric (Draeger) tubes for measuring ammonia concentration, and

- Three SUMMA ${ }^{\text {TM }}$ canisters (with the necessary tritium traps and canister particulate air filters) to collect gas samples in the event the combustible gas level in a tank exceeds the established threshold.

In addition, tracer gas injections for tanks $241-\mathrm{AX}-152$ and $241-\mathrm{A}-417$ will require the following equipment:

- Tracer gas injection and sampling systems as shown in Figures 1 and 2, respectively,

- A supply of bottled helium gas,

- SUMMA ${ }^{\mathrm{TM}}$ canisters (with canister particulate air filters),

- A tritium trap for each SUMMA ${ }^{\text {TM }}$ canister and canister particulate air filters for radiation screening, and

- Temperature gauges to measure ambient and helium gas bottle temperatures.

Spare equipment for contingency will be available as required by standard operating procedures (SOPs) for the instruments or as determined by the sampling cognizant engineer 
HNF-4082 Rev. $\varnothing 1$ DuN 6/3/99

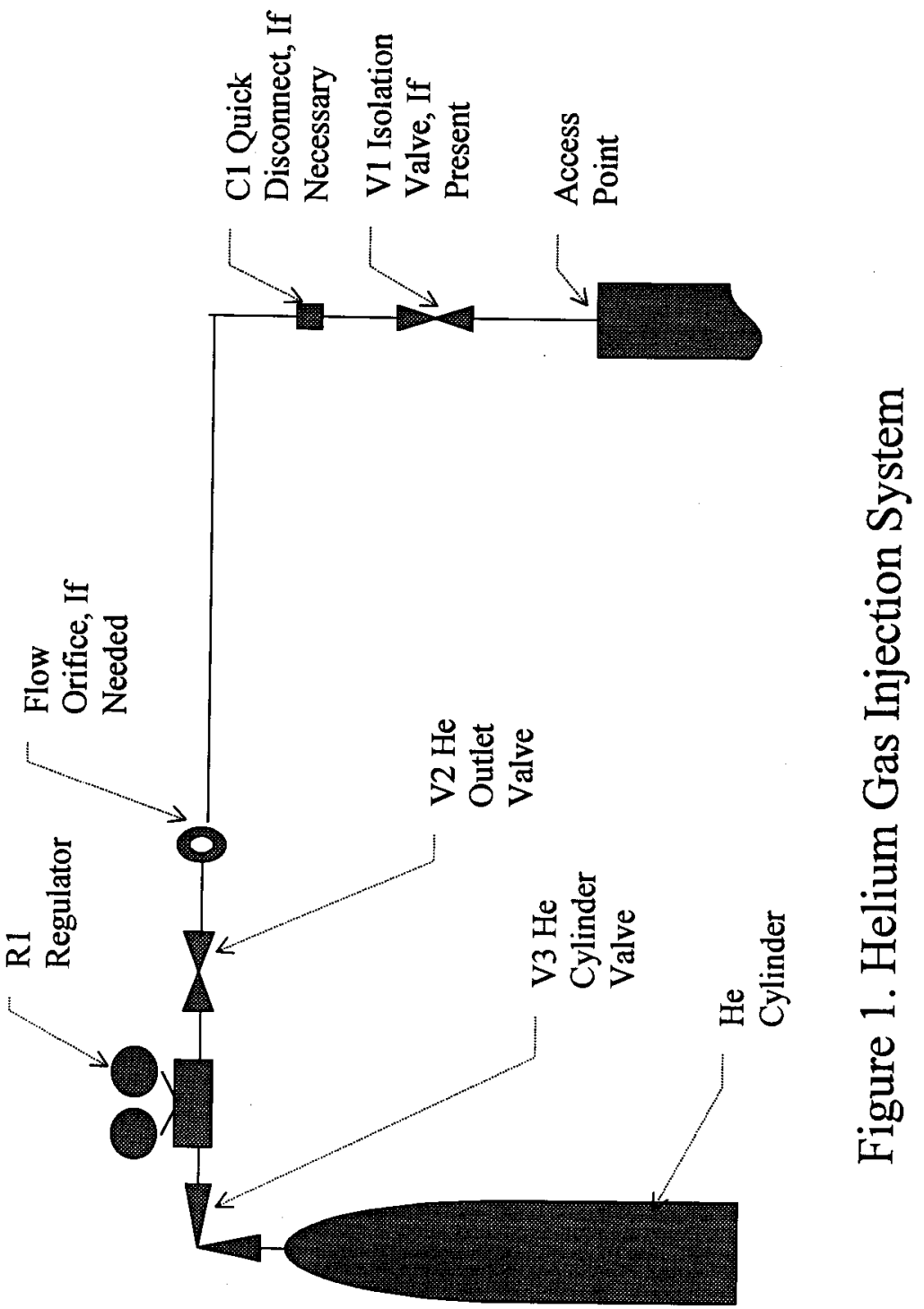


HNF-4082 Rev. $\varnothing_{1}$ ospot $0 / 3 / 44$

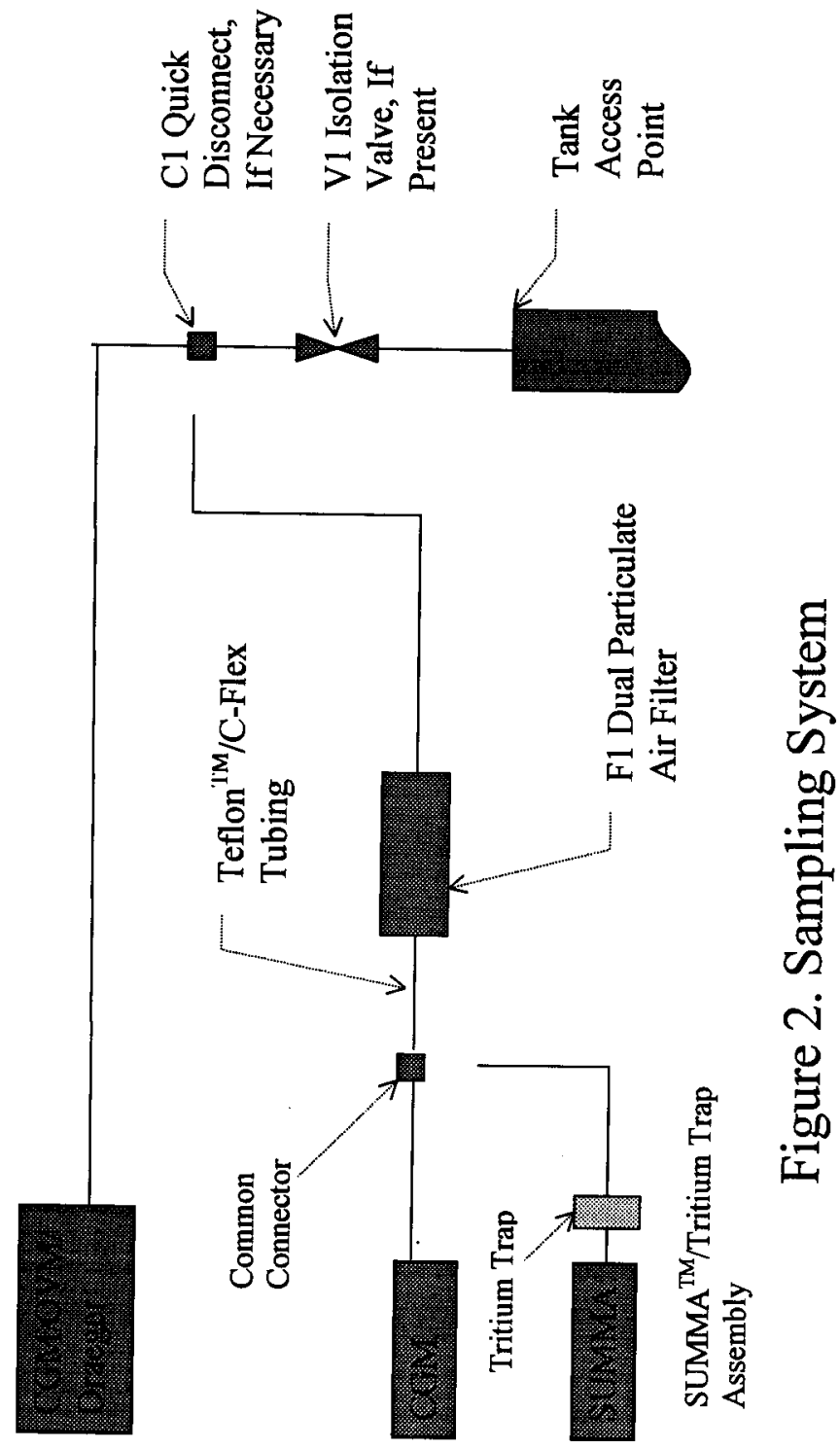




\subsection{SAMPLE IDENTIFICATION}

Each SUMMA ${ }^{\mathrm{TM}}$ sample will be labeled with a unique identification number. This number will also be recorded in the appropriate box on the data sheet form (see Appendix B). Each sample identification number will have the following format:

\section{VXXXXX-YY-LLLL}

Where,

$\mathrm{V}$ indicates that the sample is a vapor sample

XXXXX indicates the tank number (e.g., UX302 or 0A350)

YY: a two-digit code found on the data sheet

LLLL: a laboratory assigned code found on a tag attached to the SUMMA ${ }^{\mathrm{TM}}$ canister.

\subsection{DATA QUALITY REQUIREMENTS}

\subsection{REQUIREMENTS FOR FIELD DATA}

Test data that will be required from field operations of the tracer gas injection system are identified in the data sheet shown in Appendix B. Anomalies and environmental conditions that could affect sampling results (e.g., usual odors, machinery in operation nearby, etc.) will be noted in the Comments/Observations section of the data sheet. Other data (combustible gas level, organic vapor and ammonia concentrations) shall be recorded as directed in field work packages.

\subsection{REQUIREMENTS FOR LABORATORY DATA}

SUMMA ${ }^{\mathrm{TM}}$ samples collected during tracer gas injection will be analyzed for He concentration only. In the event that the combustible gas level in a catch tank exceeds the established threshold, the SUMMATM samples collected for vapor gas characterization will be analyzed for the parameters listed in Table 3-2. Suggested laboratory analytical methods and the associated required quantitation limits (RQL), precision, and accuracy for these target analytes are shown in Table 7-1. The analyses shall be performed in accordance with laboratory-approved procedures. 
HNF-4082 Rev. 1

Table 7-1. Suggested Analytical Methods and Laboratory Quality Control Requirements (2 Sheets)

\begin{tabular}{|c|c|c|c|c|}
\hline Amalyite & $\begin{array}{l}\text { Suggested } \\
\text { Anity tical } \\
\text { Method }\end{array}$ & (pproy) & $\begin{array}{l}\text { Precision. } \\
(\% \mathrm{RSD} \text { or } \\
\text { \% } \mathrm{RuD})^{2}\end{array}$ & (\%) Recovery) \\
\hline Carbon monoxide & $G C^{3}$ & 5.0 & 25 & 70 to 130 \\
\hline Carbon dioxide & $\mathrm{GC}^{3}$ & 5.0 & 25 & 70 to 130 \\
\hline Helium & $\mathrm{GC}^{3}$ & 5.0 & 25 & 70 to 130 \\
\hline Hydrogen & $\mathrm{GC}^{3}$ & 5.0 & 25 & 70 to 130 \\
\hline Methane & $\mathrm{GC}^{3}$ & 5.0 & 25 & 70 to 130 \\
\hline Oxygen & $G C^{3}$ & 5.0 & 25 & 70 to 130 \\
\hline Nitrous oxide & $\mathrm{GC}^{3}$ & 5.0 & 25 & 70 to 130 \\
\hline Ammonia & $\begin{array}{l}\text { Solvent Tube } \\
\text { Train/ IC }\end{array}$ & 5.0 & 25 & 70 to 130 \\
\hline Freon 12 & $\mathrm{GC}^{\prime} \mathrm{MS}^{3}$ & 5.0 & 25 & 70 to 130 \\
\hline Methyl chloride & $\mathrm{GC} / \mathrm{MS}^{3}$ & 5.0 & 25 & 70 to 130 \\
\hline n-Butane & $\mathrm{GC} / \mathrm{MS}^{3}$ & 5.0 & 25 & 70 to 130 \\
\hline Ethyl chloride & $\mathrm{GC} / \mathrm{MS}^{5}$ & 5.0 & 25 & 70 to 130 \\
\hline Ethanol & GC/MS ${ }^{3}$ & 5.0 & 25 & 70 to 130 \\
\hline Freon 11 & $\mathrm{GC} / \mathrm{MS}^{3}$ & 5.0 & 25 & 70 to 130 \\
\hline Acetonitrile & $\mathrm{GC} / \mathrm{MS}^{5}$ & 5.0 & 25 & 70 to 130 \\
\hline Acetone & $\mathrm{GC} / \mathrm{MS}^{3}$ & 5.0 & 25 & 70 to 130 \\
\hline Furan & $\mathrm{GC} / \mathrm{MS}^{3}$ & 5.0 & 25 & 70 to 130 \\
\hline n-Pentane & $\mathrm{GC} / \mathrm{MS}^{3}$ & 5.0 & 25 & 70 to 130 \\
\hline 2-Propanol & $\mathrm{GC} / \mathrm{MS}^{5}$ & 5.0 & 25 & 70 to 130 \\
\hline Dichloromethane & $\mathrm{GC} / \mathrm{MS}^{5}$ & 5.0 & 25 & 70 to 130 \\
\hline 1-Propanol & $\mathrm{GC} / \mathrm{MS}^{5}$ & 5.0 & 25 & 70 to 130 \\
\hline 2-Methyl-pentane & $\mathrm{GC} / \mathrm{MS}^{5}$ & 5.0 & 25 & 70 to 130 \\
\hline Propanenitrile & $\mathrm{GC} / \mathrm{MS}^{3}$ & 5.0 & 25 & 70 to 130 \\
\hline Butanal & $\mathrm{GC}^{\mathrm{M}} \mathrm{MS}^{5}$ & 5.0 & 25 & 70 to 130 \\
\hline 1-Hexene & $\mathrm{GC} \mathrm{MS}^{5}$ & 5.0 & 25 & 70 to 130 \\
\hline 2-Butanone & $\mathrm{GC} / \mathrm{MS}^{\mathrm{S}}$ & 5.0 & 25 & 70 to 130 \\
\hline n-Hexane & $\mathrm{GC} / \mathrm{MS}^{5}$ & 5.0 & 25 & 70 to 130 \\
\hline Chloroform & $\mathrm{GC} / \mathrm{MS}^{3}$ & 5.0 & 25 & 70 to 130 \\
\hline Tetrahydrofuran & $\mathrm{GC} / \mathrm{MS}^{3}$ & 5.0 & 25 & 70 to 130 \\
\hline 1-Butanol & $\mathrm{GC} / \mathrm{MS}^{5}$ & 5.0 & 25 & 70 to 130 \\
\hline Benzene & $\mathrm{GC} / \mathrm{MS}^{\mathrm{S}}$ & 5.0 & 25 & 70 to 130 \\
\hline $\begin{array}{l}\text { Carbon } \\
\text { tetrachloride }\end{array}$ & $\mathrm{GC} / \mathrm{MS}^{5}$ & 5.0 & 25 & 70 to 130 \\
\hline Butanenitrile & $\overline{G C / M S^{5}}$ & 5.0 & 25 & 70 to 130 \\
\hline 3-Methyl-hexane & ${\mathrm{GC} / \mathrm{MS}^{5}}^{3}$ & 5.0 & 25 & 70 to 130 \\
\hline 2-Pentanone & $\mathrm{GC}^{-\mathrm{MS}^{5}}$ & 5.0 & 25 & 70 to 130 \\
\hline n-Heptane & GC/MS & 5.0 & 25 & 70 to 130 \\
\hline 1,4-Dioxane & $\mathrm{GC} / \mathrm{MS}^{5}$ & 5.0 & 25 & 70 to 130 \\
\hline
\end{tabular}


Table 7-1. Suggested Analytical Methods and Laboratory Quality Control Requirements (2 Sheets)

\begin{tabular}{|c|c|c|c|c|}
\hline Arifyle & $\begin{array}{l}\text { Suggested } \\
\text { Analyrical } \\
\text { Method }\end{array}$ & $\begin{array}{l}\text { YPRQ1 } \\
\text { (ppby) }\end{array}$ & $\begin{array}{l}\text { Precision } \\
(\% \text { Rsi or } \\
\% \text { RPD })^{2}\end{array}$ & $(\%$ accuracy) \\
\hline $\begin{array}{l}\text { 4-Methyl-2- } \\
\text { pentanone }\end{array}$ & $\mathrm{GC} / \mathrm{MS}^{2}$ & 5.0 & 25 & 70 to 130 \\
\hline Toluene & $\mathrm{GC} / \mathrm{MS}^{3}$ & 5.0 & 25 & 70 to 130 \\
\hline 2-Hexanone & $\mathrm{GC} / \mathrm{MS}^{3}$ & 5.0 & 25 & 70 to 130 \\
\hline n-Octane & $\mathrm{GC} / \mathrm{MS}^{5}$ & 5.0 & 25 & 70 to 130 \\
\hline Tetrachloroethylene & ${\mathrm{GC} / \mathrm{MS}^{3}}^{3}$ & 5.0 & 25 & 70 to 130 \\
\hline Chlorobenzene & $\overline{\mathrm{GC} / \mathrm{MS}} \mathrm{S}^{3}$ & 5.0 & 25 & 70 to 130 \\
\hline Ethylbenzene & GC/MS ${ }^{5}$ & 5.0 & 25 & 70 to 130 \\
\hline $\mathrm{m}, \mathrm{p}$-Xylene & $\mathrm{GC} / \mathrm{MS}^{3}$ & 5.0 & 25 & 70 to 130 \\
\hline 3-Heptanone & GC/MS ${ }^{5}$ & 5.0 & 25 & 70 to 130 \\
\hline 2-Heptanone & GC/MS ${ }^{5}$ & 5.0 & 25 & 70 to 130 \\
\hline Cyclohexanone & $\overline{\mathrm{GC} / \mathrm{MS}^{3}}$ & 5.0 & 25 & 70 to 130 \\
\hline Styrene & ${\mathrm{GC} / \mathrm{MS}^{5}}^{-}$ & 5.0 & 25 & 70 to 130 \\
\hline n-Nonane & GC/MS ${ }^{3}$ & 5.0 & 25 & 70 to 130 \\
\hline o-Xylene & GC/MS ${ }^{3}$ & 5.0 & 25 & 70 to 130 \\
\hline $\begin{array}{l}1,1,2,2- \\
\text { Tetrachloroethane }\end{array}$ & GC/MS ${ }^{5}$ & 5.0 & 25 & 70 to 130 \\
\hline 2-Octanone & GC/MS ${ }^{5}$ & 5.0 & 25 & 70 to 130 \\
\hline n-Decane & GC/MS ${ }^{5}$ & 5.0 & 25 & 70 to 130 \\
\hline $\begin{array}{l}1,2,4- \\
\text { Trimethylbenzene }\end{array}$ & $\mathrm{GC} / \mathrm{MS}^{5}$ & 5.0 & 25 & 70 to 130 \\
\hline
\end{tabular}

${ }^{1}$ VPRQL: Vapor Program Required Quantitation Limit

${ }^{2}$ RSD: Relative Standard Deviation; RPD: Relative Percent Difference

${ }^{3} \mathrm{GC}$ : Gas Chromatography

${ }^{4}$ IC: Ion Chromatography

${ }^{5}$ GC/MS: Gas Chromatography/Mass Spectrometry

Analytical instruments shall be calibrated and maintained according to laboratory procedure(s) or manufacturer's recommendation. Analytical procedures shall be reviewed for concurrence by RPP Process Engineering prior to analysis. Personnel performing the analyses shall be appropriately trained for their assigned tasks. Calibration, maintenance, and training records shall be available for review when requested by the customer.

Traceability of the SUMMA ${ }^{\mathrm{TM}}$ samples shall be maintained through field chain-of-custody and sample shipping/receiving documentation. Laboratory chain-of-custody and/or operating log shall be used to establish traceability for every sample (and sub-sample) undergoing analysis. These records shall also be available upon request. 


\subsection{ROLES AND RESPONSIBILITIES}

The main functions for this activity include an Overall Activity Lead, Field Measurements/Sampling, Laboratory Analysis, and Data Evaluation. All functions must be executed well in order to achieve the test objectives. The relationships among these functions are shown in Figure 3. The functions and the responsible organizations are further discussed below.

Activity Lead: RPP Process Engineering, representing Safety Issue Resolution, will act in this role. The Activity Lead shall coordinate the entire effort to assure that the desired data will be obtained as scheduled. Specific responsibilities include establishing test specification (i.e., prepare this test plan), assigning task responsibilities, and resolving sampling issues as they occur.

Field Measurement/Sampling: This function consists of pre-work planning activities and the actual field sampling. RPP Characterization Engineering will be responsible for completing the pre-work planning. Specific responsibilities include preparing work packages, performing Unreviewed Safety Question (USQ) screening, conducting field verification of sampling locations, and verifying final configuration of the test equipment. In addition, RPP Characterization Engineering will communicate and obtain necessary approvals from RPP Double-Shell Tank and Single-Shell Tank Engineering groups.

Characterization Project Operations (CPO) will be responsible for coordinating and performing the fieldwork. Specific responsibilities include arranging the necessary resources (personnel, materials, and equipment) for each sampling event and collecting data and samples as specified in this test plan. In addition to ensuring the availability of primary personnel (i.e., sampler and Industrial Hygiene), CPO will coordinate secondary support such as Radiation Protection and Crafts as needed. CPO will assure that field measurements are taken and recorded properly and that SUMMA ${ }^{\text {TM }}$ samples will be traceable through proper identification and chain-of-custody. 


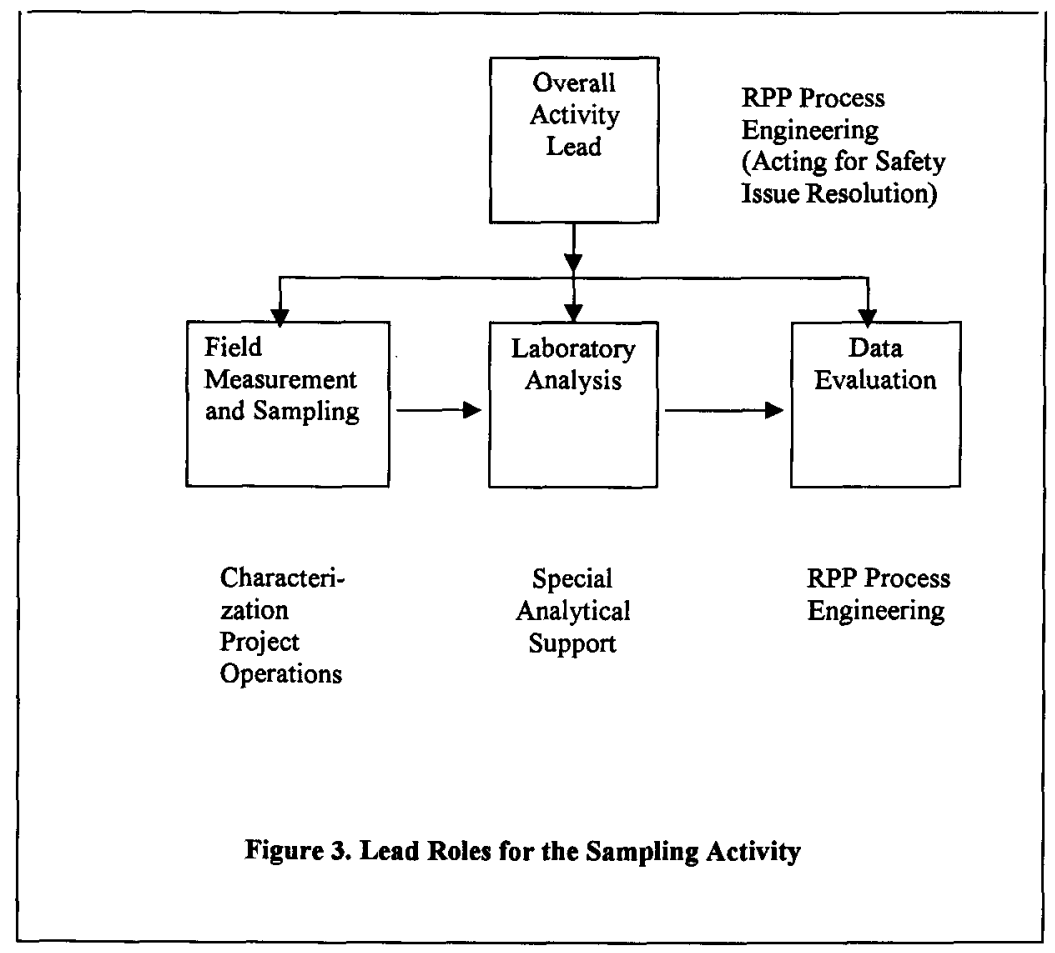


Laboratory Analysis: SUMMA ${ }^{\mathrm{TM}}$ samples will be analyzed for helium concentrations or analytes listed in Table 3-2 as appropriate. Special Analytical Support (SAS) will supply clean SUMMA ${ }^{\mathrm{TM}}$ canisters and tritium traps and be responsible for performing the analysis.

All analytical data shall be independently reviewed and approved by qualified personnel. A data report shall be transmitted to the Activity Lead only and shall contain the following information at a minimum:

- A brief narrative of the sample preparation, analysis, and quality control/quality assurance measures,

- Concentration(s) of target analyte(s) for each sample,

- Quality control data to document achieved precision and accuracy, and

- Appropriate RQL if an analyte is not detected.

In addition, the data report shall include a discussion of every characterization issue or data anomaly, resolution of each issue/anomaly, and the impact on the data.

Data Evaluation: Analytical data will be evaluated against process knowledge and existing data if available. Ventilation rates for tanks 241-AX-152 and 241-A-417 will be calculated. RPP Process Engineering will be responsible for performing this evaluation. Results of the evaluation and a summary of the data will be documented in a report.

\subsection{SAFETY CONSIDERATIONS}

Pressurized helium in steel bottles will be used for the tracer gas injection. Proper precautions will be taken when handling pressurized gas bottles. The catch tanks may contain hazardous vapor and radionuclides. A survey for hazardous vapor will be performed prior to gaining access to a tank. Also, radiation and hazardous vapor will be monitored during the test as necessary. 


\subsection{TEST PROCEDURE}

\subsection{TRACER GAS INJECTION}

Note: For catch tanks 241-AX-152 and 241-A-417, the combustible gas level measurements (See Section 10.2) must be completed prior to performing tracer gas injection.

\section{Helium Injection Procedure (Refer to Figure 1):}

1. Verify that the gas cylinder contains helium at pressure $<800$ psig.

2. Connect a single ended, shut-off, quick disconnect body (e.g., Swagelok part \#QC4), if necessary, to the assigned attachment point for the sample.

3. Connect the helium injection system to the assigned tank access point at connection $\mathrm{Cl}$, if present, as directed by the field work package.

4. Verify that the helium outlet valve is closed.

5. Measure the helium cylinder starting pressure by opening the helium cylinder valve (V3), and adjust the pressure regulator as specified in the work package.

6. Record the starting helium cylinder starting pressure as indicated by the pressure regulator digital high-pressure stage gauge.

7. Measure and record the helium cylinder temperature.

8. Open the assigned sample line isolation valve (V1), if present.

9. Begin tracer gas injection by opening the helium outlet valve (V2).

10. Observe the bottle pressure as indicated by the digital high-pressure stage gauge on the pressure regulator. When the pressure reaches the stopping pressure as specified in the work package, stop helium flow by closing the helium outlet valve (V2).

11. Close the assigned sample line isolation valve (V1), if present.

12. Verify that the helium outlet valve (V2) is closed.

13. Measure the helium cylinder final pressure using the digital high-pressure stage gauge; record the helium cylinder final pressure.

14. Close the helium cylinder valve (V3). 


\section{HNF-4082 Rev. 1}

15. Disconnect the helium injection system as directed by the field work package.

\section{Procedure for Collecting the First Set of SUMMA ${ }^{\text {TM }}$ Samples for Gas Injection (Refer to} Figure 2):

16. Verify that the specified time interval has elapsed since completion of the helium injection.

17. Connect (in series) two particulate air filters to the sample line as shown in Figure 2. The particulate air filters (F1) shall be closest to the tank access point.

18. Place a short piece of Teflon ${ }^{\mathrm{TM}}$ (or c-flex) tubing down stream of the dual particulate air filter (F1).

19. Connect the CGM/OVM to the Teflon ${ }^{\mathrm{TM}}$ (or c-flex) tubing.

20. Open the sample line isolation valve (V1), if present.

21. Purge the sample line using the CGM/OVM for the duration specified in the field work package.

22. Close the isolation valve (V1), if present.

23. Disconnect the CGM/OVM from the Teflon ${ }^{\mathrm{TM}}$ (or c-flex) tubing.

24. Connect the SUMMA ${ }^{\mathrm{TM}} /$ tritium trap assembly.

25. Open the isolation valve (V1), if present.

26. Collect the first SUMMA ${ }^{\mathrm{TM}}$ sample per field work package and record the data required on the data sheet.

27. Close the isolation valve (V1), if present.

28. Disconnect the SUMMA ${ }^{\mathrm{TM}} /$ tritium trap assembly from the Teflon ${ }^{\mathrm{TM}}$ (or c-flex) tubing.

29. Repeat Steps 24 through 28 to collect the second SUMMA ${ }^{\text {TM }}$ sample.

30. Configure the assigned tank access point to the condition specified in the fieldwork package. 
Procedure for Collecting the Second Set of SUMMATM Samples for Gas Injection (Refer to Figure 2):

31. Verify that the specified time interval has elapsed since completing collection of the first set of SUMMA ${ }^{\text {TM }}$ samples.

32. Repeat Steps 17 through 30 to collect the second set of SUMMA ${ }^{\text {TM }}$ samples.

Procedure for Collecting the Optional Third Set of SUMMA ${ }^{\text {TM }}$ Samples for Gas Injection (Refer to Figure 2):

33. Verify that the specified time interval has elapsed since completing collection of the second set of SUMMA ${ }^{\mathrm{TM}}$ samples.

34. Repeat Steps 17 through 30 to collect the optional third set of SUMMA ${ }^{\text {TM }}$ samples.

\subsection{FIELD COMBUSTIBLE GAS LEVEL MEASUREMENTS}

Ammonia concentration, organic vapor and combustible gas levels in tank headspace shall be measured after purging the sample line with headspace gas. The instruments listed in Table 3-1 shall be calibrated and operated in accordance with the operating manuals by qualified personnel. The data shall be recorded as directed in field work packages.

If the combustible gas level in a tank as measured by the CGM exceeds $25 \%$ of the LFL, the following procedure will be followed to collect three SUMMA ${ }^{\mathrm{TM}}$ samples (Refer to Figure 2):

1. Connect a single ended, shut-off, quick disconnect body (e.g., Swagelok part \#QC4), if necessary, to the assigned attachment point for the sample.

2. Connect (in series) two particulate air filters to the sample line as shown in Figure 2. The particulate air filters (F1) shall be closest to the tank access point.

3. Place a short piece of Teflon $^{\mathrm{TM}}$ (or $\mathrm{c}$-flex) tubing down stream of the dual particulate air filter (F1).

4. Connect the CGM/OVM to the Teflon ${ }^{\mathrm{TM}}$ (or c-flex) tubing.

5. Open the sample line isolation valve (V1), if present.

6. Purge the sample line using the CGM/OVM for the duration specified in the field work package.

7. Close the isolation valve (V1), if present. 
8. Disconnect the CGM/OVM from the Teflon ${ }^{\mathrm{TM}}$ (or c-flex) tubing.

9. Connect the SUMMA ${ }^{\mathrm{TM}} /$ tritium trap assembly.

10. Open the isolation valve (V1), if present.

11. Collect the first SUMMA ${ }^{\mathrm{TM}}$ sample per field work package.

12. Close the isolation valve (V1), if present.

13. Disconnect the SUMMA ${ }^{\mathrm{TM}} /$ tritium trap assembly from the Teflon ${ }^{\mathrm{TM}}$ (or $\mathrm{c}$-flex) tubing.

14. Repeat Steps 9 through 13 to collect the second and third SUMMA ${ }^{\mathrm{TM}}$ samples.

15. Configure the assigned tank access point to the condition specified in the fieldwork package.

\subsection{RADIATION SCREENING}

Tritium traps and particulate air filter assemblies will be shipped by CPO to the Waste Sampling and Characterization Facility (WSCF) for analysis. The tritium traps will be analyzed for tritium; the air filters will be analyzed for total alpha, total beta, and gamma energy analyses. Radiation Protection will use the data to determine whether or not the SUMMA ${ }^{\mathrm{TM}}$ samples can be radiologically released (and therefore can be accepted by the laboratory). CPO will store the SUMMA ${ }^{\mathrm{TM}}$ samples until they are released and will ship them to the laboratory at that time.

\subsection{REFERENCES}

Bauer, R. E., 1998, Test Plan for Headspace Gas Concentration Measurements and Headspace Ventilation Rate Measurements for DCRTs 241-A-244, 241-BX-244, 241-S-244, and 241-TX-244, HNF-2543, DE\&S Hanford, Inc., Richland, Washington.

Bauer, R. E. and Hedengren, D. C., 1999, Headspace Gas Concentration Measurements and Headspace Ventilation Rate Measurements for Double-Contained Receiver Tanks 241-A-244, 24I-BX-244, 24I-S-244, and 241-TX-244, HNF-2923, Rev. 0-A, DE\&S Hanford, Inc., Richland, Washington. 
HNF-4082 Rev. 1

This page intentionally left blank. 
HNF-4082 Rev. 1

APPENDIX A

METHOD FOR CALCULATING VENTILATION RATE IN A CATCH TANK

A-1 
HNF-4082 Rev. 1

This page intentionally left blank 
HNF-4082 Rev. 1

\section{METHOD FOR CALCULATING VENTILATION RATE IN A CATCH TANK}

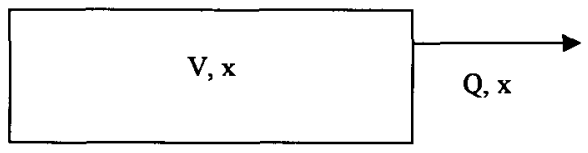

Where V: volume of headspace (volume of tank - volume of liquid)

$\mathrm{Q}$ : ventilation rate

X: concentration of helium at any given time after gas injection

Mass balance for helium:

Rate of helium out - Rate of helium in $=$ Rate of helium loss

The rate of helium entering the tank after completion of gas injection can be considered negligible. The mass balance equation can be re-written as:

$$
\begin{array}{r}
Q x=-V \frac{d x}{d t} \\
\text { Or } \quad d t=\frac{-V}{Q} \frac{d x}{x}
\end{array}
$$

Integration of Equation (2) gives:

$$
\begin{aligned}
\int_{1}^{2} d t & =\frac{-V}{Q} \int_{1}^{2} \frac{d x}{x} \\
\Delta t & =\frac{-V}{Q}\left(\ln x_{2}-\ln x_{1}\right) \\
\Delta t & =\frac{V}{Q} \ln \frac{x_{1}}{x_{2}} \\
\text { Or } \quad Q & =\frac{V}{\Delta t} \ln \frac{x_{1}}{x_{2}}
\end{aligned}
$$

$\mathrm{x}_{1}$ and $\mathrm{x}_{2}$ will be determined from analysis of the SUMMA ${ }^{\mathrm{TM}}$ samples. $\Delta t$ is the time interval between collection of the two sample sets. 
Equation (3) can be re-written as follow for the period between gas injection and collection of the first set of SUMMA'M samples $\left(\Delta t_{o}\right)$ :

$$
Q=\frac{V}{\Delta t_{o}} \ln \frac{x_{o}}{x_{1}}
$$

$\mathrm{x}_{0}$, the initial concentration of helium in the tank, can be estimated as follows:

Assume helium behaves as an ideal gas:

$$
\begin{aligned}
& \mathrm{PV}=\mathrm{nRT} \\
& n R=\frac{P_{c} V_{c}}{T_{c}}=\frac{P_{o} V_{o}}{T_{o}}
\end{aligned}
$$

Where $P_{c}, V_{c}$, and $T_{c}$ are pressure, volume, and temperature of helium in the gas cylinder and $P_{0}, V_{0}$, and $T_{0}$ are the same properties of helium in the catch tank immediately after injection.

Equation (5) can be re-arranged to:

$$
V_{o}=V_{c} \frac{P_{c}}{P_{o}} \frac{T_{o}}{T_{c}}
$$

The initial concentration of helium in the catch tank after completion of the gas injection is:

$$
x_{o}=\frac{V_{o}}{V}
$$

Three significant assumptions are associated with the calculation of $\mathrm{x}_{0}$ : one, helium behaves like an ideal gas; two, ambient temperature is the same as that in the tank vapor space (This assumption is necessary because there are no temperature probes in the catch tanks); and three, the rate of helium loss during gas injection is negligible. Because of these assumptions, ventilation rates should be calculated based on data from analyses of the SUMMA'M samples. If necessary, calculation of the ventilation rate using helium gas bottle data will be performed for verification. 
HNF-4082 Rev, 1

APPENDIX B

DATA SHEET FOR USE WITH TRACER GAS INJECTION

B-1 
HNF-4082 Rev. 1

This page intentionally left blank.

B-2 
HNF-4082 Rev. 1

TRACER GAS INJECTION DATA SHEET

Catch Tank Number:

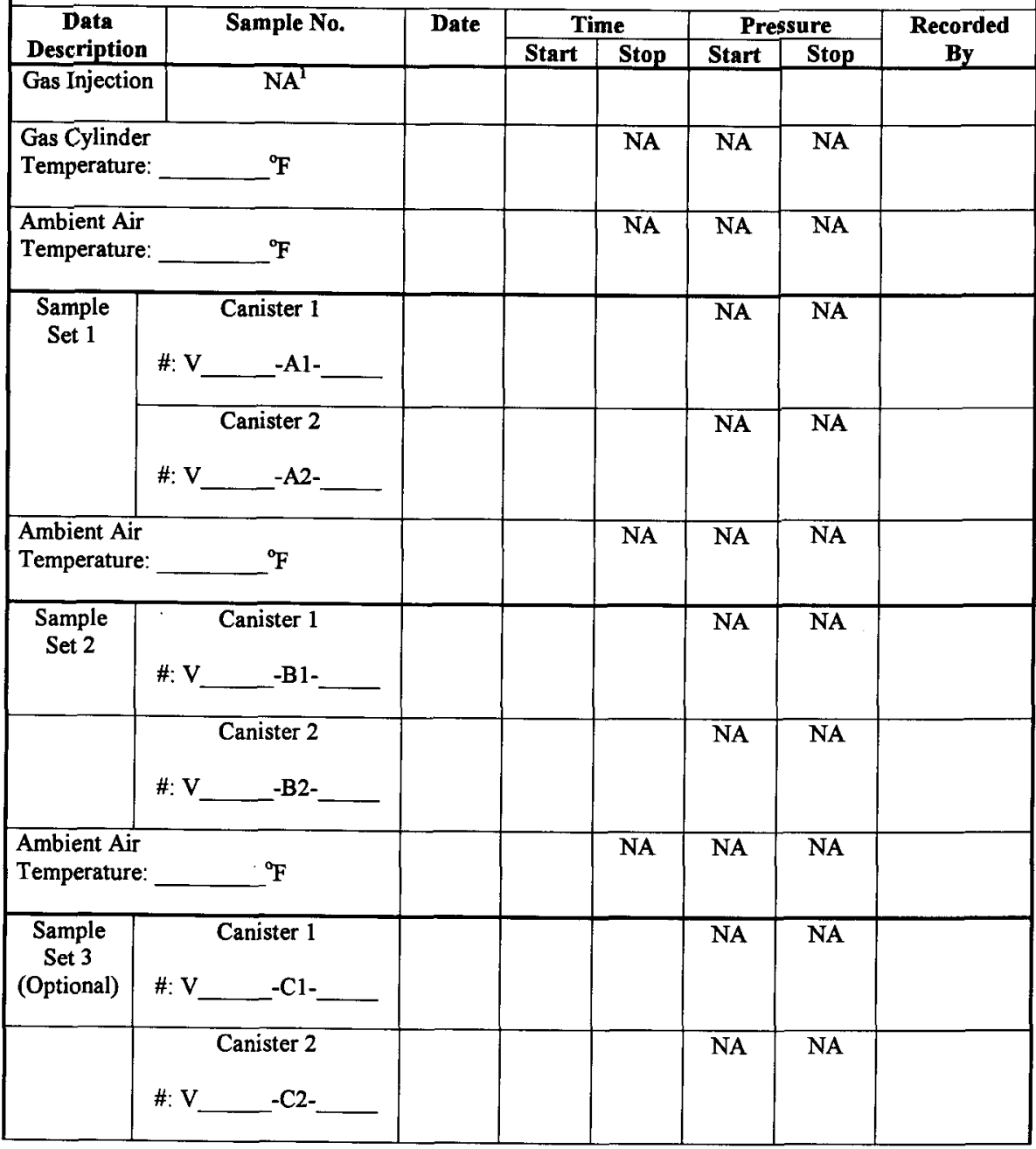


HNF-4082 Rev. 1

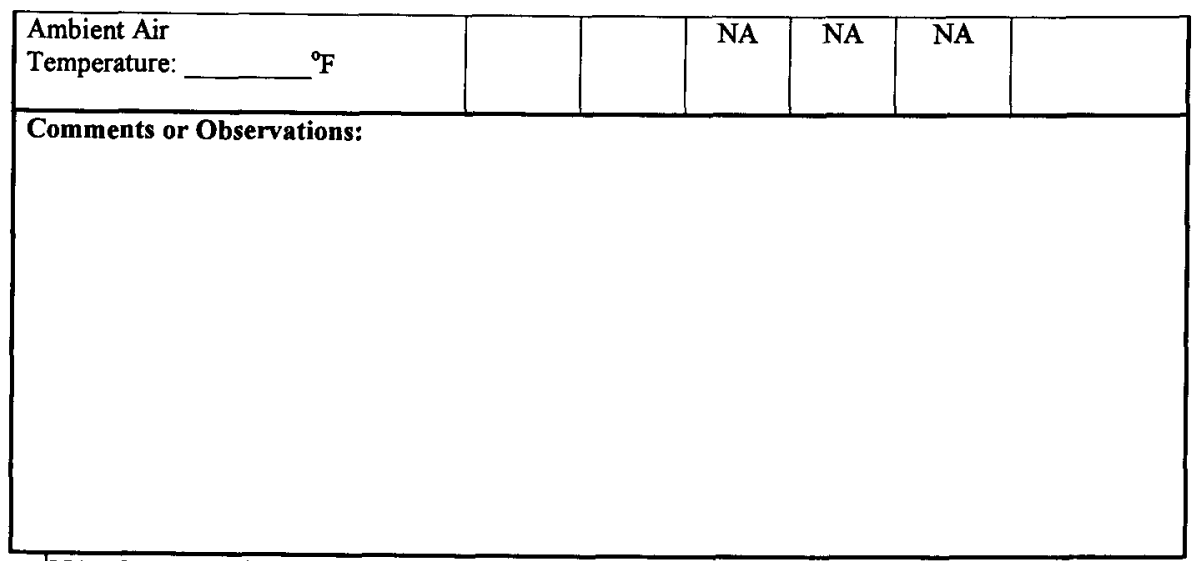

${ }^{\mathrm{N} A}$ : Not Applicable

Note: Temperature measurements should be performed during (or as close as possible to) the gas injection or sampling. 


\begin{tabular}{|c|c|c|c|c|c|}
\hline \multicolumn{6}{|c|}{ DISTRIBUTION SHEET } \\
\hline \multirow[b]{2}{*}{ Distribution } & \multirow{2}{*}{\multicolumn{3}{|c|}{$\begin{array}{l}\text { From } \\
\text { Models and Inventory }\end{array}$}} & \multicolumn{2}{|l|}{ Page 1 of 1} \\
\hline & & & & \multicolumn{2}{|c|}{ Date $\quad 06 / 01 / 99$} \\
\hline \multicolumn{4}{|l|}{ Project Title/Work Order } & \multicolumn{2}{|c|}{ EDT No. $N / A$} \\
\hline \multicolumn{4}{|c|}{$\begin{array}{l}\text { HNF-4081, Rev. 1, "Test P1an for Measuring Ventilation Rates and } \\
\text { Combustible Gas Levels in RPP Active Catch Tanks" }\end{array}$} & \multicolumn{2}{|c|}{ ECN No. ECN-653821 } \\
\hline Name & MSIN & $\begin{array}{c}\text { Text } \\
\text { With } \\
\text { All } \\
\text { Attach. }\end{array}$ & Text Only & $\begin{array}{l}\text { Attach./ } \\
\text { Appendix } \\
\text { On 7y }\end{array}$ & $\begin{array}{l}\text { EDT/ECN } \\
\text { Only }\end{array}$ \\
\hline \multicolumn{6}{|l|}{ Office of River Protection } \\
\hline $\begin{array}{l}\text { Lockheed Martin Hanford Corp. } \\
\text { W. B. Barton } \\
\text { D. A. Bragg } \\
\text { R. J. Cash } \\
\text { D. J. Green } \\
\text { K. M. Hall } \\
\text { K. M. Hodgson } \\
\text { G. D. Johnson } \\
\text { L. L. Lockrem } \\
\text { D. M. Nguyen } \\
\text { J. S. Sparks } \\
\text { D. D. Wanner } \\
\text { T.C.S.R.C. }\end{array}$ & $\begin{array}{l}\text { R2-12 } \\
\text { S5-05 } \\
\text { S7-73 } \\
\text { S7-04 } \\
\text { R2-12 } \\
\text { R2-11 } \\
\text { S7-73 } \\
\text { T6-07 } \\
\text { R2 }-12 \\
\text { ST }-07 \\
\text { S7 }-12 \\
\text { R1 }-10\end{array}$ & $\begin{array}{l}x \\
x \\
x \\
x \\
x \\
x \\
x \\
x \\
x \\
x \\
x \\
x \\
x\end{array}$ & & & \\
\hline$\frac{\text { Lockheed Martin Services, Inc. }}{\text { Central Files }}$ & B1-07 & $x$ & & & \\
\hline
\end{tabular}

